UDC 615.015.34

DOI: 10.15587/2519-4852.2020.196405

\title{
COMPARATIVE CYTOTOXIC ANALYSIS OF EXTRACTS OBTAINED FROM LEAVES AND ROOTS OF SWEET FLAG (ACORUS CALAMUS L.) ON RAT BONE MARROW CELLS IN VITRO
}

\author{
L. Derymedvid, L. Korang, L. Shakina
}

\begin{abstract}
Мета дослідження: порівняти наявність і вираженість циитотоксичної активності екстрактів із листя і кореневища лепехи звичайної (Acorus calamus L), на клітини кісткового мозку щурів в умовах in vitro. Матеріали і методи. Клітини кісткового мозку щурів виділяли з діафізів стегнових кісток тварин на холоду. Для отримання різних концентрацій екстрактів з листя (ЕЛА) і кореневища (ЕКА) лепехи звичайної (Acorus calamus L.) проводили розтитровку вихідних екстрактів в імунологічному планшеті методом перекочування. Кількісна оцінка циттотоксичності включала визначення порушення цілісності клітинних мембран в тесті з трипановим синім.

Результати. ЕКА чинить циитотоксичну дію в концентраціях 0,03-1,65 г/мл, при контакті з клітинами червоного кісткового мозку щурів протягом 15 хв, збільшуючи кількість загиблих клітин на 0.48$1.56 \times 10^{6}$ у розрахунку на мілілітр $(p<0,05)$. Для ЕКА у всіх досліджених концентраціях показано наростання ефекту циттотоксичності по мірі збільшення часу контакту клітин з діючою речовиною від 15 до 90 хв. $(p<0,05)$. У той же час, ЕЛА не викликає порушень цілісності клітинної мембрани $і$ не впливає на життєздатність нативних клітин червоного кісткового мозку щурів у всіх вивчених концентраціях.

Висновки. Відсутність цитотоксичності у ЕЛА, визначеної шляхом оцінки порушення цілісності клітинних мембран в тесті з трипановим синім, свідчить про доцільність подальших фармакологічних досліджень данного екстракту для створення на його основі ефективних і безпечних лікарських засобів

Ключові слова: цитотоксичність, червоний кістковий мозок, щури, екстракт листя лепехи звичайної, кореневища лепехи звичайної
\end{abstract}

Copyright (C) 2020, L. Derymedvid, L. Korang, L. Shakina. This is an open access article under the CC BY license (http://creativecommons.org/licenses/by/4.0).

\section{Introduction}

Despite constant increase in production of synthetic medicines, herbal therapy and herbal medicines do not lose their value $[1,2]$. The terms "herbal medicine" and "herbal therapy" were first used at the beginning of the XX century by French physician Henri Leclerc (Henri Leclerc, 1870-1955). According to his definition, herbal preparations/medicines are exclusively derived from plants/herbs or their parts (stem, root, leaves, etc.). The plants themselves or their extract are used to treat various diseases $[1,2]$.

Herbal medicine has been the most widespread form of therapy in traditional medicine in many countries [1-4]. According to the WHO, almost $80 \%$ of the world's population uses herbal preparations [2-5].

Many herbal preparations have had centuries of experience as traditional medicine. And they have also been used as allopathic medicines [1, 2, 4, 5].

Sweet Flag (Acorus calamus) is an herbaceous perennial rhizome plant belonging to the Acoraceae family $[1,2,6,7]$.

There are several types of Sweet Flag (Acorus Calamus L.), which differ in the degree of polyploidy. The diploid Sweet Flag (Acorus Calamus var. Americanus) grows in North America, Eastern Europe and Asia. The infertile triploid Sweet Flag (Acorus Calamus var. Calamus) is spread from Asia to many parts of Europe, including Ukraine;

And the tetraploid Sweet Flag (Acorus Calamus var. Spurius) could be found in East Asia, Russia, Kazakhstan, Eastern Siberia, the Far East, North and Middle China, and Japan $[1,6,7]$.

Sweet Flag (Acorus Calamus L.) and its preparations have been used as medicines in many countries. They are effective in the treatment of gastritis, dyspepsia and other digestive disorders. They are also used externally for rheumatic joint pains and as disinfectants for gingivitis, stomatitis, etc. [1, 2, 6, 7].

The oils extracted from Sweet Flag root contain alkenylbenzenes, $\alpha$ - and $\beta$-azarone, and other compounds that, in addition to the therapeutic effects (antispasmodic, antimicrobial, etc.), have, unfortunately, also negative effects, such as carcinogenic effects (cause hepatocarcinomas, tumors of the small intestine in rats). They can also have mutagenic $[8,9]$ and genotoxic activity [10].

Due to the different content of $\alpha$ - and $\beta$-azarone, and other potentially toxic substances in different species of Acorus calamus, diploid types should always be preferable $[11,12]$. Due to toxicity, the use of Acorus Calamus is limited in Europe (MPC $0.1 \mathrm{mg} / \mathrm{kg}$ in food and drinks); in the USA, the food use of oils extracted from Acorus Calamus root is prohibited by FDA [13]. 
However, several studies conducted in mice did not reveal the mutagenic activity of water-soluble polysaccharides isolated from roots of Sweet Flag (Acorus cálamus $\mathrm{L})$ with intravenous, single $\left(0.5 \mathrm{LD}_{50}\right)$ and intraperitoneal administration $[8,10]$. Therefore, there is a need for further study of toxicity of various parts of Sweet Flag (leaves, roots, etc). direct cell injury

The aim. The aim of this study was to identify cytotoxic activity based on disturbance of plasma membrane integrity and to compare severity of this cytotoxic activity of de-alcoholized alcohol-water extracts obtained from the leaves and roots of Sweet Flag (Acorus Calamus L.) on rat bone marrow cells in vitro.

\section{Planning (methodology) of research}

The subject of research was an alcohol-water extract from the leaves (Leaf Extract of Acorus Calamus (LEA) and roots (Root Extract of Acorus Calamus (REA) at the Department of Botany of the National University of Pharmacy under supervision of prof. Gontovaya $\mathrm{T}$. N.

An alcohol-water extract from the leaves (LEA) and roots (REA) of the Sweet Flag was used in the experiment after evaporating alcohol, to avoid the negative effect of ethanol. Purified water was added to obtain the initial volume of extracts. It is well known, that basal in vitro cytotoxicity is a major tool adopted in predictive toxicology. Basal cytotoxicity refers to the ability of a studied chemical substance to damage living cells, in particular by compromising functional and structural features related to general cellular housekeeping. Being a rather comprehensive term, it is not surprising that the pathways leading to basal cytotoxicity are quite generic. According to in vitro basal cytotoxicity testing strategy for new chemical entities with non-substantiated toxicological profiles [14], basal cytotoxicity in a first testing round can be tested using a minimum of 2 assays to assess 2 key events, one of which is plasma membrane damage, that is analized in our study.

\section{Materials and methods}

To conduct this experiment we used rat bone marrow cells. The animals were obtained from the vivarium of the Central Scientific Research Laboratory of National University of Pharmacy (certified by the Ministry of Health of Ukraine, certificate No. 058/15 of 08/12/2015; valid until 07/12/2019), where they were kept under a standard care in accordance with sanitary and hygienic requirements.

Bone marrow was obtained according to generally accepted method [15] in modification of Problem Laboratory for Morphofunctional Researches of National Pharmaceutical University (certified by the National Accreditation Agency of Ukraine, certificate No. $2 \mathrm{H} 1422$ of 07/09/2017; valid until 06/09/2022) according to $\mathrm{SOP} / \mathrm{T} / 001.5$. Bone marrow cells were harvested from the diaphysis of the femurs with previously minimally eliminated epiphyses of 3-month-old rats by not very deep inserting a needle into the shaft of the bone and flushing it with $2 \mathrm{~mL}$ of Normal saline $(0.9 \% \mathrm{NaCl})$ into a centrifuge tube under the cold temperature. Cells were washed by centrifugation at $500 \mathrm{~g}$ for 10 minutes. After washing, in an aliquot of the suspension obtained, the total number of cells was counted and their viability was determined using the Trypan Blue dye exclusion test in Goryaev chamber, as described below. It should be noted that the bone marrow cells viability immediately after receiving was high $(94-95 \%)$ and this suggests that the method of bone marrow cells isolation is effective, as it allows obtaining a suspension with a high viability index. Finally, harvested bone marrow cells were resuspended in normal saline to a final concentration of $2.0-2.1 \times 10^{6}$ viable cells per milliliter.

So, in the work primary (freshly isolated) cells were used, which are characterized by a certain heterogeneity in comparison with cell lines. This approach without isolating certain morphotypes of bone marrow cells is justified in view of the fact that all body cells are sensitive to general cytotoxicity, regardless of their tissue origin and specialization. Given the standard conditions for rats in the Central Scientific Research Laboratory of $\mathrm{NUPh}$ and the age of the rats, it can be assumed that the bone marrow of rats, at the time of cell suspension receiving, was normal, mainly represented by different types of hematopoietic cells $[16,17]$.

To obtain different concentrations of LEA and REA, the initial extracts were titrated (concentration $1.0 \mathrm{~g} / \mathrm{mL}$ ) on an immunological plate by the rolling method. Normal saline $(0.9 \% \mathrm{NaCl})$ was used as a solvent. The following concentrations of substances were investigated: $0.5 ; 0.25 ; 0.13 ; 0.06 ; 0.03 ; 0.02 \mathrm{~g} / \mathrm{mL}$.

An equal volume of bone marrow cell suspension was added to each well of the immunological plate with the test substance. Suspension of rat bone marrow cells with normal saline was used as a test-control. A quantitative assessment of the cytotoxicity of the samples was recorded after 15, 45, 90 minutes of cells incubation with tested substances at $37 \pm 2{ }^{\circ} \mathrm{C}$. In most general cytotoxicity testing procedures, exposure times between 1 hour and 72 hours are applied depending on the analysed key mechanisms may involved in basal cytotoxicity [14]. According to paper [14] plasma membrane damage to test basal cytotoxicity can be monitored by lactate dehydrogenase release into the medium or using reporter dyes, such as propidium iodide and Trypan blue, which was used in our study. In both cases, plasma membrane damage estimation may be carried out in conditions of short-term exposure with test chemicals within 30-180 minutes, sufficient to evaluate the plasma membrane damage of a wide range of pharmacological agents [18-21]. In our work plasma membrane damage was investigated within 15-90 min exposure, taking into account the data of works on rat bone marrow cells using Trypan blue dye exclusion test for pharmacological agents $[19,20]$.

A quantitative assessment of cytotoxicity by testing plasma membrane damage was made by microscopic analysis according to $\mathrm{SOP} / \mathrm{T} / 001.5$ with counting the number of viable/non-viable cells in the Goryaev chamber using Trypan Blue dye exclusion test. Prior to staining, $10 \mu \mathrm{L}$ of cell suspension with test samples (or normal saline in control) was transferred to a microscope slide. An equal volume of $0.1 \%$ Trypan blue in Normal saline $0.9 \%$ (ie, $10 \mu \mathrm{L}$ ) was added, and the mixture was incubated at room temperature for 1-2 min. A glass coverslip was placed on the counting Goryaev chamber, and the mixture is loaded onto $1^{\text {st }}$ chamber so that the 
mixture exactly fills the chamber. The whole chamber was observed under a light microscope, and the viable/live (clear) or non-viable/dead (blue) cells were recorded.

The total number of cells per $\mathrm{mL}$ was derived from the formula (total number of cells in the whole chamber $\times$ dilution factor (i.e., 2) $\times 1000) / 0.9$; where 1000 is the number of cubic microliters in $1 \mathrm{~mL}\left(1 \mathrm{~cm}^{3}\right)$, 0.9 is the chamber volume in microliters. And the overall number of cells per $\mathrm{mL}$ was the mean derived from three replicates.

The cell death per $\mathrm{mL}$ was derived from the formula (number of dead cells in the whole chamber $\times$ dilution factor (i.e., 2) $\times 1000) / 0.9$; where 1000 is the number of cubic microliters in $1 \mathrm{~mL}\left(1 \mathrm{~cm}^{3}\right), 0.9$ is the chamber volume in microliters. And the overall cell death per $\mathrm{mL}$ was the mean derived from three replicates.

The cell viability (\%) was calculated using the formula (number of viable cells/total number of cells counted) $\times 100 \%$, and the overall cell viability was the derived from three replicates.

The data obtained during this research was analysed using the statistical program Statistica 11.0 with the determination of arithmetic mean values (M), arithmetic mean errors $(\mathrm{m})$, and significant differences between the comparison groups. When applying the methods of mathematical statistics, a significance level of $\mathrm{p}<0.05$ was adopted [22].

\section{Results of the study}

The results of the cytotoxicity study of the Sweet Flag Leaf extract (LEA) because of the compromised cell plasma integrity in a rat bone marrow are presented in Fig 1.

The results obtained indicate that LEA did not cause any toxicity to the cell membrane and did not significantly affect the viability of rat bone marrow cells in all studied concentrations ( $p>0.05)$. An increase in the time of contact of cells with the studied substance from 15 to 90 minutes also did not lead to any significant increase in the number of dead cells ( $\mathrm{p}>0.05)$.

It was found that the substance LEA, in the studied concentrations $(1.65 \mathrm{~g} / \mathrm{mL}, 0.83 \mathrm{~g} / \mathrm{mL}, 0.41 \mathrm{~g} / \mathrm{mL}$, $0.21 \mathrm{~g} / \mathrm{mL}, 0.10 \mathrm{~g} / \mathrm{mL}, 0.05 \mathrm{~g} / \mathrm{mL}$ and $0.03 \mathrm{~g} / \mathrm{mL}$ ) does not have cytotoxic effect through disturbance of plasma membrane integrity upon contact with rat bone marrow cells from 15 to 90 minutes.

The results of the cytotoxicity study of a substance obtained from the Sweet Flag Root (REA) on rat bone marrow are presented in Fig 2.

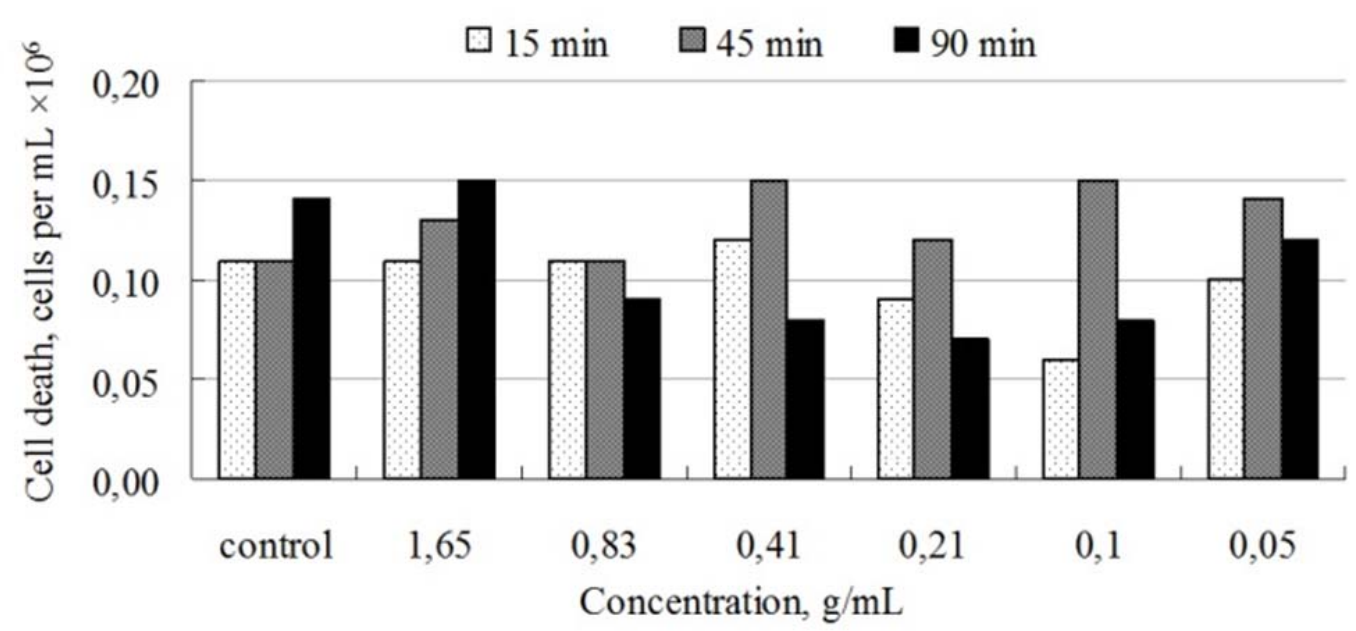

Fig. 1 . LEA cytotoxicity in rat bone marrow, $n=3$

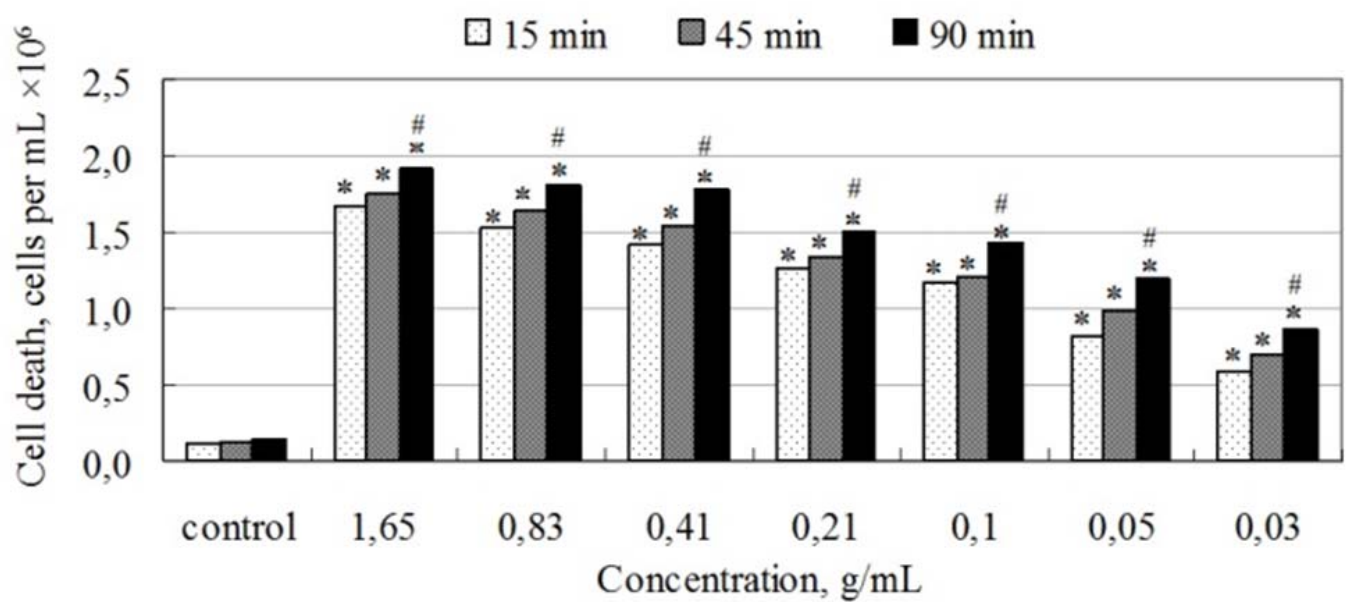

Fig. 2. REA cytotoxicity in rat bone marrow, $n=3$ :

* - the differences are significant relatively to the control, $\mathrm{p}<0.05$; $\#$ - the differences are significant between the experimental options 15 and 45, 15 and 90 minutes (depending on the time of incubation), $\mathrm{p}<0.05$ 
The results obtained indicate that the studied substance (REA) showed a cytotoxic effect via plasma membrane damage depending on the concentration and time of contact (exposure).

It was found that REA at a concentration of $1.65 \mathrm{~g} / \mathrm{mL}$ caused an increase in the number of dead cells by $1.56-1.77 \times 10^{6}$ dead cells per millilitre $(\mathrm{p}<0.05)$ in all the studied wells. The cytotoxicity effect increased with the time of contact of cells with the active substance. Similarly, at concentrations $0.83 ; 0.41 ; 0.21 ; 0.1 ; 0.05$; $0.03 \mathrm{~g} / \mathrm{mL}$ of the investigated substance REA led to an increase in the number of dead cells of rat bone marrow by $1.42-1.66,1.31-1.64,1.15-1.36,1.05-1.29,0.71-$ $1.05,0.48-0.72 \times 10^{6}$ dead cells per millilitre $(p<0.05)$, respectively, in proportion to the time of its exposure.

Thus, the studies conducted indicate the presence of cytotoxicity caused by cell membrane destruction in Sweet Flag roots and its absence in Sweet Flag leaves.

\section{Discussion of the research results}

One of the most important problems of modern preclinical studies is the problem of ethical, adequate and economical use of experimental animals [24-26]. According to the British Society for the Protection of Animals, 115 million laboratory animals are used annually in research, testing and educational purposes [24, 27].

Therefore, along with in vivo studies, in vitro methods are widely used in preclinical research systems. Their advantage, in addition to solving ethical problems associated with the use and death of experimental animals, is high technology and good reproducibility of studies, the ability to conduct screening studies of several substances at the same time, and the ability of clearly control the doses of substances that enter each cell.

These alternative studies allow you to lower the price and reduce the time of preliminary studies, minimize the number of experimental animals and partially replace them [24, 25, 27, 28].

In 1959, British scientists Russell W.M.S and Burch R.L. proposed for the first time the concept of "The three Rs", which includes three components: replacement, reduction and refinement [25].

The Refinement principle includes the use of research methods that exclude or minimize pain and stress in animals using high-quality anaesthesia, providing care for animals in the pre- and postoperative period, etc.

The Reduction principle allows obtaining the maximum possible information when using a smaller number of animals by properly planning the experiment, using animals of the required standard and genetic status.

The Replacement principle means the use of alternative research methods without conducting experiments on animals (cell and tissue cultures, computer modelling, isolated organs, etc.).

The concept of "The three Rs" is widely used in research around the world [24, 27, 28]. One of the components of alternative preclinical studies is the study of basal cytotoxicity and violation of the cell membrane integrity as a part of its first testing round.

According to the recommendations of the Interdepartmental Committee for Animal Research (USA) on the use and care of vertebrates used for testing, research and education, in vitro test methods for deter- mining basal cytotoxicity should (if possible) precede animal tests [24, 27].

Therefore, the use of the method for determining basal cytotoxicity of substances in vitro is consistent with current international trends in preclinical studies.

In our experiments, the cytotoxic activity of acorus calamus rootstalk extract caused by cell membrane destruction was established, which depends on the dose and time of contact with rat bone marrow and its absence when using acorus calamus leaves extract. In our opinion, these differences can be explained by the difference in the content of biologically active substances in these objects.

The studies conducted earlier at the Department of Botany of the National University of Pharmacy revealed and identified 33 compounds in the acorus calamus rootstalk, of which sesquiterpenoids accounted for $56.71 \%$ (of the total amount of compounds), aromatic substances $21.84 \%$ and monoterpenoids $-6.81 \%$. Among the determined and identified 42 compounds, sesquiterpenoids predominated in leaves of the acorus calamus $-37.8 \%$, aromatic compounds $-25.4 \%$ and monoterpenoids $20.6 \%$ [29]. This suggests that the overall profile of volatile compounds in the extracts also differs, which affects the results of pharmacological and toxicological studies.

Furthermore, the employees of the Department of Botany of the National University of Pharmacy identified in the acorus calamus leaves extract composition the following: phenylpropanoids - ferulic and rosmarinic acid, flavonoids (hyperoside, rutin), etc. As it is known, phenylpropanoids are the class of natural aromatic compounds, mainly of phenol nature containing one or more phenylpropane $(\mathrm{C}[6]-\mathrm{C}[3])$ fragments in the structure.

The studies of L.Ye. Nazarova established the cytoprotective and antioxidant properties of ferulic acid [30]. Moreover they are manifested both in in vitro and in vivo studies, which indicates the universality of these mechanisms of action. Antioxidant properties are inherent in rosmarinic acid. In in vitro experiments, she inhibited lipid peroxygenation processes in rat brain, liver, and kidney microsomes induced by $\mathrm{Fe} 2+$ /cysteine and vitamin C/NADPH (formation of malondialdehyde), as well as the generation of superoxide anion radical in the xanthine/xanthine oxidase system. The same properties of rosmarinic acid were also proved in vivo [31].

The cytoprotective properties of flavonoids (hyperoside, rutin, etc.) are also well described and proven. Thus, it can be assumed that due to the presence of cytoprotective biologically active substances, the extract of acorus calamus leaves did not have a cytotoxic effect on marrow cells. The lack toxicity to the cell membrane in Acorus Calamus leaves extract is the basis for further in vitro cytotoxicity testing and pharmacological studies of this substance to create new safe and effective drugs on its basis.

In our opinion, the cytotoxic effect of the extract of acorus calamus rootstalk is due to the lower content of biologically active substances with cytoprotective and antioxidant properties in the extracts. However, the question of the qualitative and quantitative composition of rootstalk extracts and acorus calamus leaves requires further in-depth studies. 
At the same time, these results may be promising for further preclinical studies of acorus calamus rootstalk extract to create cytostatics based on them for the treatment of neoplasms and autoimmune processes.

\section{Conclusions}

The cytotoxicity of the substance obtained from the Sweet Flag roots (REA) as a consequence of the compromised cell plasma integrity depends on the dose and time of contact with rat bone marrow. REA has a cytotoxic effect at concentrations of $0.03-1.65 \mathrm{~g} / \mathrm{mL}$ in contact with rat bone marrow cells for 15 minutes, causing an increase in the number of dead cells by 0.48 $1.56 \times 10^{6}$ dead cells per millilitre $(p<0.05)$. For REA in all studied concentrations, an increase in the effect of cytotoxicity is shown as the contact time of cells with the active substance increases from 15 to 90 minutes $(\mathrm{p}<0.05)$.

The substance obtained from the Sweet Flag leaves (LEA) does not cause toxicity to the cell membrane and does not significantly affect the viability of rat bone marrow cells in all studied concentrations.

The absence of cytotoxicity caused by disturbance of plasma membrane integrity in Sweet Flag leaves (LEA) indicates the need for further in vitro cytotoxicity testing and pharmacological studies of this substance to create effective and safe drugs on its basis.

\section{Conflict of interest}

Author has no conflict of interest to declare.

\section{References}

1. Harna, S. V., Vladymyrova, I. M., Burd, N. B. et. al. (2016). Suchasna fitoterapiia. Kharkiv: Drukarnia Madryd, 580.

2. Vais, R. F., Fintelmann, F. R.; Shreter, A. I. (Ed.) (2004). Fitoterapiia. Moscow: Medicina, 534.

3. Grigorian, E. R., Parfeinikov, S. A. (2015). Razvitie VOZ v oblasti narodnoi mediciny. Nauchnoe obozrenie. Medicinskie nauki, 1, 139-140.

4. WHO traditional medicine strategy 2014-2023. Available at: https://www.who.int/medicines/publications/ traditional/trm_strategy14_23/en/

5. World Health Organization (2003). WHO guidelines on good agricultural and collection practices (GACP) for medicinal plants. World Health Organization. Available at: https://apps.who.int/iris/handle/10665/42783

6. Kamil, S. S., Hameed, I., Hamza, L. F. (2017). Acoruscalamus: Parts used, Insecticidal, Anti-Fungal, Antitumour and Anti-Inflammatory Activity: A Review. International Journal of Pharmaceutical Quality Assurance, 8 (3), 153-157. doi: http://doi.org/10.25258/ijpqa.v8i03.9578

7. Umamaheshwari, N., Rekha, A. (2018) Sweet flag: (Acarus calamus) - An incredible medicinal herb. Journal of Pharmacognosy and Phytochemistry, 7 (6), 15-22.

8. Gurev, A. M., Belousov, M. V., Akhmedzhanov, R. R., Iusubov, M. S., Voronova, O. L., Karpova, G. V., Churin, A. A. (2010). Issledovanie mutagennykh svoistv vodorastvorimykh polisakharidov aira bolotnogo. Eksperimentalnaia i klinicheskaia farmakologiia, 8, 43-45.

9. Patel, D. N., Ho, H. K., Tan, L. L., Tan, M.-M. B., Zhang, Q., Low, M.-Y. et. al. (2015). Hepatotoxic potential of asarones: in vitro evaluation of hepatotoxicity and quantitative determination in herbal products. Frontiers in Pharmacology, 6. doi: http://doi.org/10.3389/fphar.2015.00025

10. Durnev, A. D., Lapitskaya, A. S. (2012). Genotoksikologiya soedineniy rastitelnogo proishoideniya. Ecological Genetics, $\mathrm{X}(3), 41-52$.

11. European Medicines Agency Evaluation of Medicines for Human Use. Doc Ref: EMEA/HMPC/139215/2005 (2005). London, 7.

12. Public statement on the use of herbal medicinal products containing asarone. (2005). Committee on herbal medicinal products (HMPC). European Medicines Agency Evaluation of Medicines for Human Use. Doc Ref: EMEA/HMPC/139215/2005. London, 7.

13. PDR for Herbal medicines (2004). 147-148.

14. Vinken, M., Blaauboer, B. J. (2017). In vitro testing of basal cytotoxicity: Establishment of an adverse outcome pathway from chemical insult to cell death. Toxicology in Vitro, 39, 104-110. doi: http://doi.org/10.1016/j.tiv.2016.12.004

15. Meirelles, L. da S., Nardi, N. B. (2003). Murine marrow-derived mesenchymal stem cell: isolation,in vitroexpansion, and characterization. British Journal of Haematology, 123 (4), 702-711. doi: http://doi.org/10.1046/j.1365-2141.2003.04669.x

16. Fiziologicheskie, biokhimicheskie i biometricheskie pokazateli normy eksperimentalnykh zhivotnykh (2013). Saint Petersburg: Izd-vo «LEMA», 116.

17. Kolot, N. (2017). The study of bone marrow cells in rats according to their age and caloric intake. ScienceRise: Biological Science, 1 (4), 9-13. doi: http://doi.org/10.15587/2519-8025.2017.93632

18. Eropkin, M. Yu. (2004). Kultury kletok kak modelnaya sistema v biokhimiko-toksikologicheskikh issledovaniyakh. Saint Petersburg, 354.

19. Zupanecz, I. A., Vetrova, E. V., Sakharova, T. S., Dobrova, V. E. (2014). Korrekcziya proizvodnymi glyukozamina destabiliziruyushhego vliyaniya doksorubiczina na kletki kostnogo mozga krys v opytakh «in vitro». Vestnik VGU. Seriya: Khimiya. Biologiya. Farmacziya, 3, 128-132.

20. Dobrova, V. Ye., Zupanecz, I. A., Maloshtan, L. M., Stepanova, K. O. (2011). Validacziya metodiki viznachennya vplivu destabilizuyuchikh chinnikiv na modeli kistkovogo mozku shhuriv. Klinichna farmacziya, 15 (2), 18-21.

21. Chekanova, V. A., Khanina, L. A., Mazalov, V. K., Lugovoi, V. I. (1995). Czitotoksichnost i krioprotektornaya aktivnost oksietilirovannykh amidov pri kriokonservirovanii kletok kostnogo mozga krys. Problemy Kriobiologii, 2, 35-40.

22. Lapach, S. M., Chubenko, A. V., Babich, P. N. (2001). Statisticheskie metody v mediko-biologicheskikh issledovaniiakh s primeneniem Exel. Kyiv: Morion, 408.

23. Gildeeva, G. N. (2015). Aktualnye problemy doklinicheskikh issledovanii: perekhod k alternativnoi in vitro-toksikologii. Vestnik Roszdravnadzora, 5, 59-62.

24. Gericke, C. (2011). Was Sie Schon immer uber Tierversuche wissen wollten. Ein Blick hinter die Kulissen. Gottingen: Echo Verlag, 99. 
25. Russell, W. M. S., Burch, R. L. (1959). The Principles of Humane Experimental Technique. Methuen. London, 88-91.

26. Taylor, K., Gordon, N., Langley, G., Higgins, W. (2008). Estimates for Worldwide Laboratory Animal Use in 2005. Alternatives to Laboratory Animals, 36 (3), 327-342. doi: http://doi.org/10.1177/026119290803600310

27. Schuppli, C. A., Fraser, D. (2005). The Interpretation and Application of the Three Rs by Animal Ethics Committee Members. Alternatives to Laboratory Animals, 33 (5), 487-500. doi: http://doi.org/10.1177/026119290503300511

28. Korshun, M. N., Krasnokutskaia, L. M. (2005). Princip «trekh R» i puti ego realizacii v toksikologo -gigienicheskikh issledovaniiakh. Ukrainskii zhurnal z problem medicini praci, 3-4, 66-73.

29. Hontova, T. M., Taller, O. Yu. (2014). Doslidzhennia komponentnoho skladu efirnoi olii lystia lepekhy zvychainoi. Zb. nauk. pr. spivrobitnykiv NMAPO im. P. L. Shupyka, 23 (4), 254-259.

30. Nazarova, L. E. (2012). Issledovanie citoprotektornoi aktivnosti kisloty ferulovoi. Piatigorsk, 47.

31. Alekseeva, L. I., Bolotnik, E. V. (2013). Rozmarinovaia kislota i antioksidantnaia aktivnost Prunella grandiflora i Prunella vulgaris (lamiaceae). Rastitelnii mir Aziatskoi Rossii, 1 (11), 121-125.

Received date 04.12.2019

Accepted date 12.02.2020

Published date 29.02.2020

Lyudmyla Derymedvid, MD, Professor, Department of Pharmacology, National University of Pharmacy, Pushkinska str., 53, Kharkiv, Ukraine, 61002

E-mail: derimedved67@gmail.com

Lyudmyla Korang, Postgraduate Student, Department of Pharmacology, National University of Pharmacy, Pushkinska str., 53, Kharkiv, Ukraine, 61002

E-mail: ludakorang@gmail.com

Lyubov Shakina, PhD, Assistant, Department of Human Anatomy and Physiology, National University of Pharmacy, Pushkinska str., 53, Kharkiv, Ukraine, 61002

E-mail: LyubovZ2003@gmailcom 